\title{
The PRotection of PeRsonAL AND PROPERTY RIGHTS ACT 1988 - UPDATE AND REFLECTIONS
}

\author{
Bill Atkin*
}

This article coincides with the 25th anniversary of the passage of the Protection of Personal and Property Rights Act 1988. The Act provides mechanisms for decision-making on behalf of people who lack capacity to make decisions for themselves. It is of increasing importance as the population ages. The article looks at the origins of the legislation and its contemporary focus. Recent case law is explored and some challenges for the future outlined. While the need for the Act remains, it may be timely for a fuller review to be undertaken.

\section{INTRODUCTION}

The Protection of Personal and Property Rights Act 1988 (PPPRA) was enacted 25 years ago. It is timely to review how the Act has operated and what its future holds. This article does not however purport to summarise all that has happened since it was passed, nor critically evaluate each step of the way. It dips into a few topics that have exercised the courts in the last few years and offers a few contemporary reflections.

After a brief outline of what the Act covers, the article looks at why the Act was passed and how it slotted into the broad legislative context of the day. ${ }^{1}$ Then, before a consideration of a range of specific issues in relation to property and financial matters, personal decision-making and enduring powers of attorney, a few current issues of general relevance are raised. Three over-arching topics are then given particular attention: how well does the Act work when urgent action is needed, how are court orders enforced, and where does the High Court's inherent jurisdiction fit in?

* Professor, Faculty of Law, Victoria University of Wellington. This is a revised version of a paper delivered at the LexisNexis Family Law Masterclass Conference, Auckland 12 June 2013. Thanks to Tom Cunningham for his research assistance in the preparation of this article.

1 For some earlier thoughts on the Act, see W R Atkin "The Courts, Family Control and Disability - Aspects of New Zealand's Protection of Personal and Property Rights Act 1988" (1988) 18 VUWLR 345. 
In general terms, the PPPRA has stood the test of time. Nevertheless, some of its provisions are tired and may need sharpening. Amendments were made in 2007 to enduring powers of attorney, ${ }^{2}$ but a full scale "check-up" is worth considering in the near future.

\section{A SKELETAL OUTLINE OF THE ACT}

The PPPRA is essentially about incapacity. It provides a structure for dealing with adults ${ }^{3}$ who lack the capacity to make decisions for themselves. One judge has recently described the Act as "prophylactic legislation for the benefit of those who are unable to manage their personal and property affairs". ${ }^{4}$ In other words, it is not an ambulance at the bottom of a cliff, but a means of providing for the present and future needs of those with incapacities.

A fundamental distinction between personal and property matters underlies the Act. Prior to the Act, legislation provided for the High Court to make orders with respect to property, ${ }^{5}$ but no equivalent existed for personal issues. The latter could have been the subject of the High Court's inherent parens patriae jurisdiction but rarely was this used. ${ }^{6}$ The provisions on personal issues thus represent gap-fillers, but much more than this, they fill a genuine need. One suspects that much was done in the preceding era without any real legal authority.

The Act contains several important mechanisms. First, the Family Court can make direct personal orders on a range of specific matters affecting the subject person. Some of the most important such decisions relate to health and residence, including institutionalisation. Secondly, the court can appoint a welfare guardian, who will typically have wide-ranging powers to make personal decisions on an ongoing basis on behalf of the person concerned. An appointment can however be tailored to particular issues. A welfare guardian will not be appointed if some other lesser course of action will serve the purpose: it tends to be an order of last resort. The court can also appoint a property manager, who may be an individual or a trustee corporation. This will not happen if very little property remains - s 11 enables the court to empower someone to handle the administration of small amounts of property and income without all the conditions attaching to full property management. ${ }^{7}$ Finally, the Act allows for a competent person to grant "enduring powers of

2 See Part VII below.

3 A person must be 18 or over, or else be married, in a civil union or de facto relationship for a personal order to be made, per s 6(2). A narrow exception is found in s 12(3) where the child is effectively without a guardian or parent. A property order can be made in relation to a minor but this is likely to be extremely rare. WJT v PJT [Attorney's decisions: costs] [2012] NZFC 3763, [2012] NZFLR 855 at [13] per Judge Turner.

The Aged and Infirm Persons Protection Act 1912 and Part VII of the Mental Health Act 1969.

6 This topic is touched on later in Part X.

7 As happened in Treneary v Treneary [2009] NZFLR 1062 (HC); see also.[2009] NZFLR 208 (FC). 
attorney". These relate to either personal or property matters, and often both kinds will be granted at the same time. This enables a trusted person to be chosen ahead of time for the purpose of acting when the donor of the power loses capacity. ${ }^{8}$ An ordinary power of attorney cannot achieve this result because it expires when the donor loses capacity. Thus, prior to the PPPRA, powers of attorney were useless at the very time when they would often have been most valuable. The Act again filled a lacuna. The ability to create an enduring power is a perfect example of the exercise of personal autonomy and, in the judge's words quoted above, is "prophylactic".

\section{TWENTY-FIVE YEARS AGO}

When the PPPRA was enacted 25 years ago, it was a forward-thinking piece of legislation. Most of the drive for its enactment came from organisations representing those with intellectual handicaps. One of the main aims was to "normalise" the lives of such individuals as much as possible, as part of a wider social policy agenda. To a large extent, the focus was on human rights, so that those with handicaps would not be seen as abnormal, or be dealt with paternalistically and often out of sight. The emphasis was more on the rights of the individuals concerned than on shielding them from the rest of society. Hence, the title of the Act is about protecting rights rather than protecting the "infirm", as in the repealed Aged and Infirm Persons Protection Act 1912.

The Act tied in with the new mood of the late 1980s: away from interventionist policies and towards greater freedom for the person and for business. Other legislation followed: the Children, Young Persons, and Their Families Act 1989, which has a minimum intervention principle in s 13(b)(ii), the New Zealand Bill of Rights Act 1990 (largely about individual rights), and the Mental Health (Compulsory Assessment and Treatment) Act 1992, which contains a set of patients' rights. The PPPRA should not therefore be seen in isolation. Nevertheless, some stark contrasts emerge when it is compared with the other legislation, especially the 1989 and 1992 Acts.

The Children, Young Persons, and Their Families Act 1989 was passed one year after the PPPRA. The former deals with vulnerable children, the latter vulnerable adults, and yet they are remarkably different. One of the hallmarks of the Children, Young Persons, and Their Families Act 1989 is the family group conference (FGC). This is the central decision-making body under the Act and, in contrast to the child protection teams that were planned in the original version of the legislation, the focus is on those who hopefully have the child's welfare most at heart, especially the wider family group and whānau. As an aside, it is odd to see the 2012 White Paper on vulnerable children reintroducing "Children's Teams" with "lead professionals", raising uncertainties about the role of the FGC. ${ }^{9}$

8 A property power can come into effect immediately if desired (s 97(4)), but not a personal one (s 98).

9 The White Paper for Vulnerable Children (Ministry of Social Development, Wellington, 2012) vol 1 at 14 and vol 2 at 117. Curiously, professional teams are not included in the recently introduced Vulnerable Children Bill 2013. 
For present purposes, it is relevant to note that the PPPRA contains no notion of the FGC and indeed no principle that refers to the importance of cultural values in deciding what might happen to a person with incapacity. In a recent case, the idea was floated that the terms of a welfare guardian's appointment should include the holding of family meetings, which might be particularly appropriate for Māori subject to the Act. ${ }^{10}$ The Judge decided not to add this requirement. Under s 18(4)(c), a welfare guardian has a consultation obligation, and the Judge considered that consultation with family members could be achieved without specifying it formally: ${ }^{11}$

If the parties agree to meet from time to time that will be a matter for them. To require such meetings by

order, without addressing all the implications ... would in all probability cause more trouble than good.

The Mental Health (Compulsory Assessment and Treatment) Act 1992 (MHA) was passed just 4 years after the PPPRA and also deals with vulnerable adults, those suffering from a "mental disorder" as defined in s 2(1). Section 4 expressly excludes certain categories, including "intellectual disability", unless the person in question also suffers from a mental disorder. While the PPPRA operates only after a Family Court order (except for enduring powers of attorney), the MHA incorporates a more medicalised model, so that initial compulsory assessment and treatment can occur without judicial intervention. This gives flexibility for dealing with immediate problems but raises issues about proper process, given the nature of the intervention and infringement of individual liberties. The Family Court thus has a role later on if intervention is to continue, and the Mental Health Review Tribunal, rather than the Family Court, handles reviews.

The key "objectives" of the PPPRA are the "least restrictive intervention principle" and the empowerment principle, under which people subject to the Act are encouraged to exercise what capacities they have to the greatest possible extent. ${ }^{12}$ The PPPRA also contains a presumption of competence. ${ }^{13}$ It is fascinating that none of these is found expressly in the MHA. On the other hand, the PPPRA does not have a streamlined approach for acting quickly comparable to the MHA. ${ }^{14}$

\section{TWENTY-FIVE YEARS ON}

How does the PPPRA look now, 25 years later? Before looking more closely at various specific issues, three general matters are considered.

10 CJ of Wairarapa, Social Worker v BNW of Masterton [2012] NZFLR 931 (FC) especially at [31]-[35] per Judge Ellis.

11 At [35].

12 Sections 8 and 28.

13 Sections 5 and 24.

14 However, see the discussion of "urgent action" in Part VIII. 


\section{A Statistics}

The PPPRA is used quite frequently, although some cases may involve reviews of existing orders or further litigation relating to the same person. According to a Ministry of Justice consultation paper, produced as part of the Family Court review, figures over the five year period from 2004/05 to 2009/10 show that the number of substantive applications per year is over 2000: for example, in 2009/10 there were 2573 applications. ${ }^{15}$ Of the vast proportion of applicants over the combined period, who presumably reflect the people who were the subject of applications, 85 per cent were New Zealand European/pākehā, compared with 9 per cent Māori, and 3 per cent Pacific over the combined period 2004/05 to 2009/10.

It is interesting to compare the corresponding figures for mental health cases, which are 61 per cent, 21 per cent and 10 per cent. The significant difference may reflect several things. Perhaps because of socio-economic factors, pākehā may have more property that requires management. The formal appointment of substitutes to handle personal and property matters may be more suitable for pākehā, whereas other cultures may have more communal ways of dealing with such issues. The figures may also reflect varying levels of mental health issues among different cultural groups and perhaps the higher proportion of elderly persons among the European/pākehā population. According to the Ministry of Justice paper, the average number of days for disposing of a PPPRA case is well over a year, the longest of any Family Court proceedings. It is not clear why this should be so and the figures may need to be treated with suspicion.

\section{B Family Court Review}

The review of the Family Court has created its own degree of turmoil, with the Family Court Proceedings Reform Bill 2012 attracting significant criticism. Accordingly, the Minister of Justice announced a major back-track, which was incorporated into the report-back from the select committee and in the final enactment. The effect of the review on the PPPRA should nevertheless be minimal. The reforms are designed to maintain protection for the vulnerable, and the approach of the PPPRA, including the crucial appointment of a lawyer to represent the subject person, is not under threat. The amendments to the PPPRA are small; for example, they include replacing references to "barrister or solicitor" with "lawyer" and adding ss 65A and 65B under which a lawyer to assist the court can be appointed (although this already occurs frequently).

\section{The UN Convention}

Another development that may yet have an impact on the PPPRA is the Disabilities Convention. ${ }^{16}$ New Zealand ratified the Convention and it was the subject of the Disability (United

15 Reviewing the Family Court: A public consultation paper (Ministry of Justice, Wellington, 2011) at 81 and following.

16 United Nations General Assembly Convention on the Rights of Persons with Disabilities GA Res 61/106, A/RES/61/106 (2007). 
Nations Convention on the Rights of Persons with Disabilities) Act 2008. However, the 2008 Act is simply a series of amendments to other statutes and does not expressly include the Convention itself (in contrast for example to the Hague conventions on inter-country adoption and child abduction and the United Nations Convention on the Rights of the Child as found in the Children's Commissioner Act 2003).

So far, the Convention has not played a significant role in many PPPRA judgments. This is perhaps unsurprising, as the Convention is in many ways geared to the situation of those with physical disabilities. Arguably a number of articles, including article 12 on "equal recognition before the law" and the enjoyment of "legal capacity on an equal basis with others in all aspects of life", do not sit well with the PPPRA. However, article 12 recognises that measures to assist people who lack capacity are necessary so long as they are "proportional and tailored to the person's circumstances". It requires that "[t]he safeguards shall be proportional to the degree to which such measures affect the person's rights and interests". Arguably, the objectives mentioned above, especially that of the least restrictive intervention, actually conform well to the language of the Convention. The question of the proportional approach may still need to be kept constantly at the forefront of our minds.

The main case where the Convention has been raised was an extraordinary one. JMG $v$ CCS Disability Action (Wellington Branch Inc) ${ }^{17}$ involved two people with Down's syndrome who lived together in a flat rented by the woman, JMG. The man, JCE, was subject to the PPPRA and CCS Wellington was having trouble accessing the flat to provide JCE with various services. The problem appears to have been orchestrated and driven by JMG's mother. The end result was that the Court, using s 10(4), ${ }^{18}$ vested the tenancy in both JMG and JCE, with additional orders relating to CCS's access to the flat.

The outcome shows the extent of the PPPRA's reach and the ingenious way in which the Act can be used to reach a desired solution. However, our interest is in the argument that the woman raised in relation to the Convention. She argued that the order with respect to the tenancy breached her Convention rights, citing article 19 (living independently and being included in the community), article 22 (respect for (privacy) and article 23 (respect for home and family). ${ }^{19}$ The Family Court judge turned this argument on its head, stating that it "fundamentally missed" the point that the Convention rights applied to both parties, not just to JMG. ${ }^{20} \mathrm{JCE}$ had chosen to live with JMG and

$17 J M G$ v CCS Disability Action (Wellington Branch Inc) [2012] NZFLR 369 (HC). See also the Family Court decision in CCS Disability Action v JCE [2011] NZFLR 696 (FC).

18 The power in s 28A of the Property (Relationships) Act 1976 in relation to tenancies was also noted, but not invoked in the case.

19 CCS Disability Action v JCE, above n 17, at [24]. See also JMG v CCS Disability Action (Wellington Branch Inc), above n 17, at [20].

20 CCS Disability Action v JCE, above n 17, at [26]. 
was entitled to the services that CCS was endeavouring to provide, which facilitated his being able to live in the community. On appeal, Miller J did not undertake any analysis of the Convention, but in upholding the approach of the Family Court, he impliedly supported the approach taken to the Convention.

The CCS Disability Action litigation saw the Convention used in the end to support the course of action taken. It was designed to prevent the subject person from being exploited and manipulated. We may yet see more case law emerging where the Convention deters orders from being made.

\section{PROPERTY ISSUES}

The first aspect of the PPPRA to be explored in more detail relates to the role of property management. The first of several issues concerns litigation on tort liability going to the Supreme Court.

\section{A Statutory Duties and Tort}

The most significant recent case involving property managers is undoubtedly Johnston $v$ Schurr. ${ }^{21}$ The plaintiff, who had been in negotiations with his wife over a relationship property settlement, suffered a motorbike accident leaving him with serious brain injuries. Schurr was appointed as his property manager under the PPPRA, but because he had been the family accountant for many years, the appointment excluded the power to settle relationship property for fear of a possible conflict of interest. After the plaintiff had sufficiently recovered (described as "a remarkable recovery"), he eventually finalised the relationship property issues but, because of the delay of several years and increase in the value of the parties' farm, the settlement cost him much more than it would if it had been settled earlier.

In these circumstances, the plaintiff argued that the property manager had not fulfilled his duties under the Act by failing to get the terms of his appointment amended or the appointment of a comanager to settle the relationship property matters. Johnston sued the property manager in the tort of breach of statutory duty and his previous solicitors in negligence. He failed in both, and also failed in an application to amend his pleadings by adding a claim in negligence against the property manager. Our interest is primarily with the case against the property manager.

The tort of breach of statutory duty is notoriously difficult to establish and depends on the court's reading into the statute an intention to provide a private right of action for a limited class of persons whom the Act is designed to protect. $^{22}$ A complication for the plaintiff here was s 49 PPPRA, which states:

21 Johnston v Schurr [2012] NZFLR 753 (CA), [2011] NZFLR 114 (HC). The Supreme Court has granted leave to appeal: Johnston v Schurr [2012] NZSC 101.

22 See generally S Todd (ed) The Law of Torts in New Zealand (6th ed, Thomson Reuters, Wellington, 2013) at $\operatorname{ch} 8$. 
... no action shall lie against a manager in respect of anything done or omitted to be done by the manager in the exercise of the powers conferred by or under this Act, unless it is shown that the manager acted in bad faith or without reasonable care.

So, to try and cover himself, the plaintiff pleaded that the manager was under a duty to act in good faith and with reasonable care. ${ }^{23}$ The Court of Appeal, upholding the decision of Duffy J, gave three reasons why the tort did not apply in this case. ${ }^{24}$ First, the existence of s 49 meant that a claim in breach of statutory duty could not exist simpliciter, as it had to be tied to a lack of reasonable care or bad faith. Furthermore good reasons for s 49 existed: ${ }^{25}$

The legislature may have chosen to protect managers in that way because they may be unpaid volunteers or family members and theirs is a difficult role, requiring them to balance the subject person's wishes and interests in light of his or her degree of competence...

Secondly, because of s 49 , the plaintiff may have to prove a want of reasonable care and "[s]uch action would seem to add nothing to an action in negligence, in which the legislative context would inform the duty of care question". Thirdly, according to the Court: ${ }^{26}$

... the statute contains its own enforcement mechanisms. Managers must file reports or risk criminal penalties, and the Public Trust may audit their reports and enforce managers' duties. The Family Court has a supervisory role, and it will review appointments or decisions from time to time or on application. We accept Mr Carruthers' submission that the Public Trust's powers under s 37 supply an imperfect remedy, in that they attach only to managers who are not trustee corporations. But the remedy available against managers who are not trustee corporations is broad: s 37 allows the Public Trust to file civil proceedings "for any breach of duty".

Thus, while the PPPRA is designed to protect a specific class of people, the scheme of the Act does not indicate any legislative intention to provide a private claim in tort for breach of the Act, a fortiori when such a claim has to be tied with negligence or bad faith in any event.

The Court of Appeal compounded the plaintiff's woes by adding that, even if a cause of action existed, it would not have been breached. In short, this was because the manager's appointment excluded the pursuit of relationship property matters for reasons of conflict of interest. How could a manager be expected to seek the very powers that the earlier court had denied?

The plaintiff belatedly sought to add negligence as a cause of action. The Court of Appeal accepted that a duty of care in negligence may arise under the PPPRA, ${ }^{27}$ but in this case no

23 Johnston v Schurr (CA), above n 21, at [63].

24 At [87]-[89].

25 At [87].

26 At [89]. 
evidence of breach of such a duty had been advanced. On the relevant standard of care, the Court usefully said the following: ${ }^{28}$

In the absence of any previous decisions, the standard of care required of a property manager is not settled. Nor is the standard of care self-evident: it must depend heavily upon the context, which includes the subject person's degree of competence, the nature of the property under management, the Family Court's reasons for appointing a given manager, the manager's skills, the appointment or involvement of others to assist the manager, and the scope of the manager's powers.

In light of this standard, the court saw the plaintiff facing "formidable obstacles". ${ }^{29}$ Again, the question comes back to the express restriction placed on Schurr's role as manager: it is hard to find someone in breach of a standard of care for failing to do something that they were barred from doing by law.

It remains to be seen how the Supreme Court will address these issues. It is hard to see the claim for breach of statutory duty succeeding. On negligence, it is likely to accept that a duty of care may arise, but will it give the plaintiff the chance to lead evidence of breach despite the "formidable obstacles"? One may well sympathise with the plaintiff who had already suffered twice: his serious injuries by accident and the less than generous property settlement. However, as the latter was largely a question of how the inflationary increase in the farm should be divided as between himself and his former wife, this was not exactly a case of loss.

One issue that Johnston $v$ Schurr did not cover was whether the property manager was under a fiduciary duty towards the plaintiff and whether the outcome of any claim for breach of such a duty would be any different. The likely answer is "no" for the same reasons as determined the outcome of the negligence action, but a fiduciary may be held to a higher standard. In a case about enduring powers of attorney with respect to property, it was held that the relationship is a fiduciary one and, for example, the attorney has a duty to account. ${ }^{30}$ The point surely applies to property managers appointed by the court under Part 3 of the Act.

\section{B Expenses and Financial Assistance to Others}

An issue that sometimes comes up in relation to managers is recovery of costs and remuneration. Section 50 allows recovery of expenses from the subject person's estate but not

27 At [101], citing B v Attorney-General [2004] 3 NZLR 145 (PC) and Attorney-General v Prince [1998] 1 NZLR 262 (CA), which, in the rather different context of child abuse, accepted that a duty of care may arise on the basis of the exercise of statutory authority designed to protect a particular class of people.

28 Johnston v Schurr (CA), above n 21, at [103].

29 At [105].

30 Treneary $v$ Treneary (FC), above $\mathrm{n}$ 7. The appeal to the High Court did not deal with this point: [2009] NZFLR 1062. 
remuneration unless the court orders otherwise. In CAP v GJH [Welfare guardian], ${ }^{31}$ a daughter shifted from Australia to Mount Maunganui in order to look after her father. She rented a place nearby, thus enabling her to look after him and avoid his going into a rest home. She was his welfare guardian and property manager. She sought recovery of her accommodation expenses. It was held that these did not come within s 50, as they were not essential for fulfilling management duties. However, they were recoverable under s 21 as they related to her role as welfare guardian. Had she simply been his property manager, she would have missed out.

LTA-AW $v$ LTW [Directions for property manager] ${ }^{32}$ was also a case involving a family member as manager. A dementia patient's daughter/manager proposed selling her mother's property and with the proceeds, inter alia, paying various debts, then using $\$ 100,000$ to help her brother buy a property, and setting up a fund of a similar amount to pay for her son's secondary school fees. In other words, authority was being sought to do various things that, perhaps, a parent might want for their children and grandchildren.

Judge Twaddle considered that a manager who is a family member should not usually expect remuneration but rather act out of natural love and affection. In this case, the daughter could claim only out-of-pocket expenses and could also set up a funeral trust for her mother. The larger proposed payments came under s 62 , which allows the court to approve settlements of property so long as they are the kind of thing the protected person might have done. On the facts, Judge Twaddle was not convinced that the mother, given her modest means, would have spent the money on her son, nor was there evidence of her thoughts on her grandson's education. It was instead ordered that the balance be invested, so that the mother would have a contingency fund.

Judge O'Dwyer took a rather different view in EFD $v J A D .^{33} \mathrm{~A}$ road accident victim in a permanent vegetative state was looked after by his family with love and affection. Retrospectively, he received lump sum accident compensation payments and accident compensation paid for his ongoing financial needs. Money from his funds was lent to the family trust to buy a property in Wanaka and the issue was whether the loan could be made interest-free. Following an earlier decision of Judge Inglis QC, Judge O'Dwyer held that the court is not bound to act so as to increase the subject person's assets but could step into the person's shoes and ask what he would likely do if he had capacity, a form of substitute decision-making. ${ }^{34}$ She concluded that he would have considered the interest-free loan to be an appropriate use of his money to the benefit of his parents and siblings. The son had an "interest in the broader sense of recognising consideration of his wider

31 CAP v GJH [Welfare guardian] [2008] NZFLR 473 (FC).

32 LTA-AWv LTW [Directions for property manager] [2011] NZFLR 704 (FC).

33 EFD v JAD NZFC Dunedin FAM-2006-012-000330, 27 July 2011.

34 At [37]-[39] and [43]. See also Re Lane (1989) 5 FRNZ 303 per Judge Inglis QC. 
family": there was jurisdiction for the order sought, which was "in keeping with the principles of the Act and in [the son's] best interests". ${ }^{35}$

\section{PERSONAL MATTERS}

The issues that arise in relation to matters of personal care range widely. A sample is considered here, starting with the increasingly significant topic of institutionalisation, and finishing with the appointment of welfare guardians.

\section{A Placement in an Institution}

In the earlier days of the life of the PPPRA, many cases involved people with congenital intellectual handicaps. These days, as a sign of the times, a large number of cases concern people suffering from dementia, and institutionalisation is a key issue. In terms of the Act's objectives, empowerment becomes rather academic, but the least restrictive intervention remains very relevant. For someone who is no longer able to live on their own, what should happen? Is it less restrictive to let the person remain living at their home and paternalistic to place them in a rest home?

Judge Moss provides some very helpful guidance on this question. ${ }^{36}$ In short, she says that the least restrictive intervention principle should not operate in a way that undermines the person's dignity. The case concerned a woman who vehemently wanted to stay at home, but was not coping on a number of fronts, including food and hygiene. The judge said: ${ }^{37}$

The "least restrictive intervention possible" needs also to be read congruently with the Act's long title and purpose. The word possible must be construed within the standards of health safety and life style which the subject person lived prior to losing capacity. At least that will be a standard above menial existence, in degraded, dangerous or poverty stricken circumstances. While any of these are, in the pure sense, possible, none of them are consistent with societal norms in New Zealand. Nor are they consistent with the standard of living in the community in which MJP has lived prior to losing capacity.

Furthermore:

The subject person's own standard of living and personal scruples priorities and concerns remain central to determining the least restrictive intervention. A person who has always been fiercely independent may justify the Court intervening less than a person whose disease progress has created in them isolative or highly suspicious characteristics. Commonly, and as it was in this case, families struggle with

35 At [46].

36 Hutt Valley District Health Board v MJP [2012] NZFLR 458 (FC). See also Canterbury District Health Board v MH [2012] NZFC 4432, [2013] NZFLR 312, where Judge CP Somerville held that the PPPRA would have to be used rather than the mental health legislation where the issue is essentially about the person's hygiene and feeding rather than the management of the dementia.

37 At [17] and [26] respectively. 
enabling continuation of independence, where there is an increasing level of fragility. But that alone cannot justify intervention.

On the facts, the woman was ordered to be placed in a rest home.

In Re H [Personal orders], ${ }^{38}$ Judge Burns explored the differences between s 10(1)(d) and (e). The former refers to placement in an institution, the latter "living arrangements". A difficulty was how to provide for someone who may need different levels of care at different times and in different places. The judge held that (d) and (e) were mutually exclusive. An order under (d) needed to specify the particular institution in question and could not be drafted more broadly. However, (e) allowed the problem to be overcome by an order's provision for a range of care types for the person. This flexible outcome is a common sense one.

\section{B Contact}

The question of contact comes up in some situations that bear similarities to cases involving children. ${ }^{39}$ The leading case is the decision of Ronald Young $\mathrm{J}$ in $T$ - $E v B$ [Contact], ${ }^{40}$ where an anxious woman with special needs lived with her grandmother and step-grandfather. The relationship with her mother was strained, and the Family Court allowed unsupervised contact with the mother fortnightly on Sundays. The mother appealed on the basis that this was not enough, while the grandparental caregivers cross-appealed arguing that the court had no jurisdiction to make a contact order.

Ronald Young J's judgment is interesting on two different levels. First he held that jurisdiction to make the order did exist and could be achieved by giving "living arrangements" in s 10(1)(e) a broad construction: ${ }^{41}$

In the phrase "living arrangements" the words used are generously wide and no doubt deliberately imprecise. They encompass all matters relating to where the subject person lives and what arrangements there are for living in whatever place the subject person lives. There is no reason to suppose that they are intended to be restricted to the primary care arrangement or only to overnight care. The phrase anticipates that an order may be made encompassing all the subject person's living arrangements. The potential orders that can be made, therefore, will be very wide.

... I agree with the appellant's submissions that living arrangements will include all aspects of the subject person's environment including where they live from day to day, with whom they have contact,

38 Re H [Personal orders] [2010] NZFLR 212 (FC).

39 See further discussion in B Atkin "Adult Guardianship: Some Brief Comparisons with the Law of Children" (2011) 7 NZFLJ 90.

$40 \quad T-E v$ B [Contact] [2009] NZFLR 844 (HC).

41 At [19] and [22]. 
and who they are cared by. The purpose of the order in this case is after all to facilitate contact between mother and daughter

The other level is more philosophical and goes to the heart of the legislation: ${ }^{42}$

The Act is intended to have a "rights" based focus rather than a welfare focus. Its intention is to encourage, facilitate and support the subject person. These rights in this case especially include J's rights to a family life, access to her whole family as well as to her cultural heritage.

As a footnote to this dictum, it is notable that the Act does not include the welfare and best interests of the person as the paramount consideration or as one of the objectives, even though welfare guardians and managers must act in the person's best interests.

\section{Review}

Contact issues were part of the subtext of another recent decision concerning a welfare guardian. Under s 12(8) PPPRA, the appointment of a welfare guardian is to be reviewed after three years, and under s 86(7) it can be extended for up to another three years. However, under s 86(8) in exceptional circumstances the period can be up to five years. Section 87 contains similar rules for property orders. One judge has described the three year rule as a "presumption". ${ }^{43}$ Few examples show how the discretion to extend the period to five years should be exercised. In one recent case, Judge Burns dealt with what he described, with a hint of exasperation, as "the longest single running case in the Auckland Family Court". ${ }^{44}$ The reappointment of a woman's welfare guardian was opposed by the woman's mother, whose concerns in many respects related to contact with her daughter. The mother put up an alternative candidate to be welfare guardian but who for a variety of reasons was not suitable, in particular because, being "aligned" with the mother, he would have a conflict of interest. The existing welfare guardian was held to be carrying out her role "appropriately and well" and was re-appointed. Judge Burns further decided that there were exceptional circumstances justifying a five year term of appointment. In essence the circumstances were the exceptional need of the woman for stability in contrast to the mother's attitude of re-litigating issues whenever an opportunity arose.

\section{Welfare Guardians}

Under s 12(6) only one welfare guardian can be appointed, unless exceptional circumstances mean that more than one would be in the person's interests. Only rarely will this happen, but it did in

42 At [18].

43 CJ of Wairarapa, Social Worker v BNW of Masterton, above n 10, at [40] per Judge Ellis.

$44 T W$ and $C E B W v J M W$ [2012] NZFC 9480 at [1]. See also RMM v TLM NZFC Hamilton FAM-2001-019001634, 31 January 2008 where Judge Riddell found exceptional circumstances on the facts described under the next sub-heading D. 
a case involving a woman with deteriorating intellectual and physical problems. ${ }^{45}$ She had long been looked after by her parents, who sought a joint appointment. It was held that these circumstances were exceptional. This outcome is sensible as no family conflict existed and the parents operated in tandem.

This may be contrasted with other situations where conflict does exist. In Treneary $v$ Treneary, ${ }^{46}$ a daughter of a dementia patient had been granted both property and welfare enduring powers of attorney. After the mother had been in permanent dementia care for a while, the daughter sold the mother's house. A dispute with her brother erupted over the use of the proceeds. The outcome was the Family Court's revocation of her enduring powers, and the appointment of the brother's daughter (ie a granddaughter) to be welfare guardian with powers to administer her grandmother's property under s 11 . The appeal challenged the appointment of the granddaughter as welfare guardian. Andrews J held that the Family Court judge made an error of law in choosing the welfare guardian. The focus had been on the daughter's misadministration of her mother's property while acting as attorney but no assessment had been made of the management of her role as welfare attorney. The issues of property management and welfare guardianship had therefore been conflated: the problems to do with property management did not necessarily mean that the daughter was also unsuitable to be a welfare guardian. The question was remitted to the Family Court. Treneary thus underlines how property and personal matters can be quite different, and how it may often be preferable to have separate people fulfilling the two roles.

While a property manager can receive remuneration if the court agrees under s 50 , the equivalent provision for welfare guardians, $s$ 21, refers only to recovery of expenses. The reason for this difference is that welfare guardians are expected to be volunteers and often a relative of the subject person. However, a subject person may have no family or trusted friend, or may have a family that is fighting internal battles. Finding an independent person who is willing to be appointed without any return beyond actual expenses is not easy and can be a real practical problem in implementing the Act.

The very issue arose in In the matter of Mark Woodsman.$^{47}$ Because of family feuding, an independent appointee was necessary and the ideal person was available, but only if she was remunerated - she was a "professional" welfare guardian and property manager. The judge accommodated her in a way that was pragmatic and well-motivated, but in a strict legal sense somewhat dubious. He side-stepped the absence of express provision for remuneration by using $\mathrm{s}$ 10(4), which is a "catch-all" that enables the court to make supplementary orders to help the effectiveness of the main order. He allowed remuneration at the hourly rate of $\$ 60$ plus GST up to

$45 R M M v T L M$ NZFC Hamilton FAM-2001-019-001634, 31 January 2008.

46 Treneary $v$ Treneary, above $\mathrm{n} 7$.

47 In the matter of Mark Woodsman [2013] NZFC 3907 per Judge Murfitt. Pseudonym given by the judge. 
an annual maximum of $\$ 5,000$. Any reform of the Act should surely provide expressly for this situation.

\section{ENDURING POWERS OF ATTORNEY}

We have no way of knowing how many EPAs exist in New Zealand but one may guess that the number is considerable. Unlike the United Kingdom, we do not have a system of registration, and until recently the paperwork could be done by buying forms cheaply from the local bookseller. This gave rise to the alleged potential for abuse and the Law Commission prepared a report. ${ }^{48}$ The eventual upshot was a new set of rules enacted in 2007 that placed some significant constraints on the creation and operation of EPAs. Some argued at the time that the extra formality was unnecessary. In February 2013, the Senior Citizens Minister announced a review of the 2007 changes and a public consultation as part of it, as mandated by s $108 \mathrm{AB}$ of the Act. The outcome of this review remains to be seen.

One of the main changes enacted in 2007 relates to the creation of an enduring power: s 94A. The previous simplicity was replaced with a degree of formality that some may see as excessive. In essence, a legal-type person (lawyer, trustee corporation employee or legal executive) must explain to the donor the concept of an EPA, and then witness the donor's signature. The document must be accompanied by a certification that the explanation has been given, that no reason exists to doubt the donor's mental capacity, and that the witness is independent of the attorney. The attorney must sign and have the signature witnessed by someone other than the donor's witness. A prescribed form must be used. Unlike s 14 of the Wills Act 2007, a court cannot validate an appointment that does not comply with all the requirements but under s 95(2), a non-prescribed form will be acceptable if it does not depart in any material way from the prescribed one.

The other important change relates to the activation of an EPA. A property EPA may be set up to operate straightaway or with the onset of mental incapacity. In the latter case, under s 97(8) a health practitioner must determine mental incapacity and must certify accordingly, although a court may also make the determination. In relation to a personal power, the position is more complicated. Under s 98, a health practitioner's certificate of mental incapacity or equivalent court decision is needed only where the attorney acts "in respect of a significant matter". The section gives a change of residence, entering residential care and a major medical procedure as examples of "a significant matter".

So far, these new requirements have not led to any tortuous litigation, but perhaps that day beckons. In the meantime, the issue of mental capacity to create an EPA has arisen. Potter $\mathrm{J}$ in $W v$ Public Trust [Enduring powers] ${ }^{49}$ held that the Family Court has power to determine the validity of

48 Law Commission Misuse of Enduring Powers of Attorney (NZLC R71, 2001). See also Law Commission Protections Some Disadvantaged People May Need (NZLC R80, 2002).

49 Wv Public Trust [Enduring powers] [2010] NZFLR 277 (HC). 
an enduring power, and this includes a decision that the donor was mentally capable at the time of the power's creation. Section 102 at first sight seems to cover this, but expressly refers only to whether the donor "is mentally incapable" as opposed to "capable". This did not deter Potter J, and the result is surely sensible. Potter $\mathbf{J}$ also noted that the High Court would have inherent jurisdiction in relation to this question.

One of the pre-existing safeguards against abuse of an EPA is the ability under s 103 to have an attorney's decisions reviewed. Treneary, ${ }^{50}$ discussed above in the context of welfare guardians, ${ }^{51}$ involved a challenge to the attorney's property decisions. Judge Murfitt held that it was reasonable to review the decisions because of the lack of sufficient records and the lack of reasonable care in administering the mother's resources to preserve them against loss. ${ }^{52}$

In a case involving a dispute between sisters over their late mother's affairs, Judge Walsh focused on how to determine whether it is "reasonable" to review an attorney's decisions under s 103(4). ${ }^{53} \mathrm{He}$ saw it as similar to Wednesbury unreasonableness in the context of High Court judicial review. Thus, the court could ask whether the "decision undermines the purpose of the Act, ... results in a breach of the attorney's statutory or common law duties, ... is irrational, failed to take into account relevant matters account or took into account irrelevant matters", or if it "is in the overall interests of justice" to review the decision.

WJT v PJT [Attorney's decisions: costs] ${ }^{54}$ concerned a fight between two brothers over the way in which one of them as attorney had managed their mother's funds. The claimant succeeded in the review but claimed costs after expending nearly $\$ 100,000$ in legal fees. The court considered that, given the size of the estate, this amount was difficult to justify, and so costs of $\$ 12,500$ were awarded. These took account of the attorney brother's modest financial position. The latter was also required to pay 30 per cent of the lawyer to assist's costs.

\section{URGENT ACTION}

The question can be asked about how quickly the wheels of the PPPRA can move. Is it too slow for modern-day conditions? In $N v S^{55}$ Judge Burns allowed an urgent application for an HIV patient's toxoplasmosis treatment, acknowledging a clash between the person's right to life and the right to be heard. ${ }^{56}$ In a more recent decision, $P T v M J D,{ }^{57}$ Judge Burns was faced with a similar

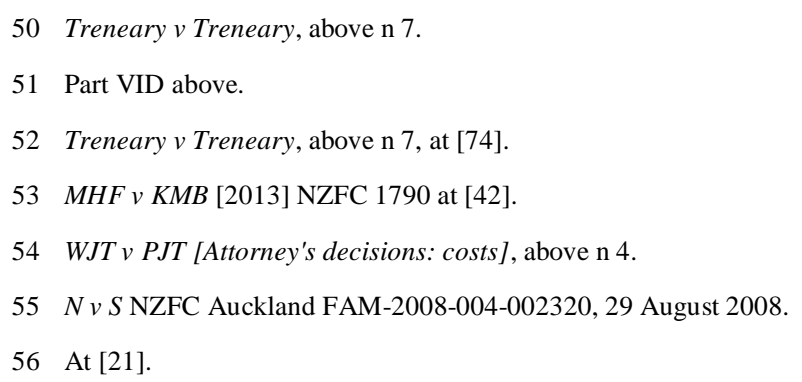


question but in the context of the extension of a temporary property order for a 77 year old woman suffering from schizo-affective disorder, made without hearing from the subject person. He held that, while there was no jurisdiction to grant an application filed on a without notice basis, there was jurisdiction to make interim orders and temporary orders for personal and property matters respectively "without the subject person being served," so long as a lawyer appointed to represent the person is ready to be heard. He noted that "[t]here is nothing in the Act which prevents an application being dealt with urgently and set down for hearing if necessary in a matter of hours". On the facts, a lawyer appointed for the woman made no representations, but only because the documentation had been sent to the wrong address. This was held to be an administrative rather than a substantive error, not rendering the extension of the property order invalid. ${ }^{58}$

\section{ENFORCEMENT}

One of the issues that has sometimes arisen in the context of the PPPRA is the enforcement of orders. ${ }^{59}$ To illustrate, in a Mental Health Review Tribunal decision, reference was made to the supposed "lack of enforcement provisions" in the PPPRA and therefore its unsuitability for dealing with mental health patients who might otherwise be released from compulsory status. ${ }^{60}$ "For example, were the Applicant directed to reside at a community support facility but leave the facility, he could not be forceably returned. In contrast, the Mental Health Act [sic] authorises police assistance in returning patients to place of treatment". ${ }^{61}$ In any event, the Tribunal thought that the mental health legislation was the better vehicle for dealing with a person who might be switched to a community treatment order from an inpatient one.

The potential overlap between the mental health legislation and the PPPRA is real but is not the point that we are exploring at the moment. ${ }^{62}$ We should note however that a court cannot order someone under the PPPRA to be placed in a psychiatric institution, because this is expressly

$57 P T v$ MJD [2013] NZFC 2706 at [19].

58 Judge Burns concluded his judgment by making a final property order in favour of the Public Trust: the woman was able to cope with her day-to-day affairs but not her financial affairs. For a case where the absence of the subject person from a pre-hearing conference invalidated a property order, see CMS v Public Trust [2008] NZFLR 640: his absence "was more than a matter of natural justice. It was a deficiency going to the validity of the hearing and order and directions made" at [78] per Keane J.

59 Protections Some Disadvantaged People May Need, above n 48, at [18] and following under the heading "Does the Protection of Personal and Property Rights Act 1988 confer coercive powers?".

$60 \operatorname{Re}$ TK (MHRT, 13/003, 4 March 2013).

61 At [85].

62 This is the subject of a chapter by the author and Judge A Skellern "Adults with Incapacity: The Protection of Personal and Property Rights Act" in John Dawson and Kris Gledhill (eds) New Zealand's Mental Health Act in Practice (Victoria University Press, Wellington, 2013). 
excluded in s 10(1)(d) PPPRA. Other forms of institutionalisation may nevertheless be the subject of an order and under s 10(1)(f) medical treatment, without limitation, can be ordered.

Some questions may still arise over how a PPPRA order is going to be enforced, and it is not clear what role the police might have in relation, for instance, to an "escapee". However, case law reveals that judges have not been reluctant to make supplementary orders under s 10(4), giving teeth to the primary order. One of the earliest examples is $\operatorname{Re} B$ [seclusion] $^{63}$ where a woman, institutionalised for most of her life because of a mental disorder of developmental origin, suffered from outbursts of violence and, on such occasions, had to be locked in a room on her own. A welfare guardian was appointed with power to delegate to the institution the decision to keep the woman in seclusion if necessary. The use of force is part and parcel of this, and Judge Inglis QC stated: 64

\footnotetext{
Accordingly I rule as a matter of law that in principle seclusion may be authorised in one way or the other under the 1988 Act in cases, as here, where it is needed from time to time to ensure the patient's own safety and welfare and the safety and welfare of others. There is power to make a personal order to that effect in terms of s 10 (f), for example. In principle a welfare guardian may be empowered to consent to the institution in which the patient is cared for providing seclusion for the patient as and when needed, in which case the welfare guardian's consent becomes in the law the patient's consent.
}

Recently Judge Moran followed Re $B$ [seclusion]. In $C D v J M T,{ }^{65}$ a mental health patient needed cancer treatment but lacked capacity to consent. The relevant treatment, including attendance at the local public hospital, was ordered. To back this up, the Judge ordered, by implication under s 10(4), that "reasonable force may be used to implement [the orders], including the administration of sedation". The Judge said that "[t]here can be no question that jurisdiction exists to use force to compel treatment where a failure to do so may compromise a person's life". ${ }^{66}$ The final words in this statement should not be seen as a limitation. In another case, a mental health patient needed dental work including the removal of teeth. ${ }^{67}$ Judge Ullrich QC ordered this, with the important rider of "Restraint and/or sedation if such restraint and/or sedation are necessary to ensure that [the person] receives the medical treatment specified above".

The question of force is taken a step further in a case concerning a person with severe alcohol dependence, who in the opinion of a doctor was "literally drinking himself to death". ${ }^{68}$ While people

63 Re B [seclusion] (1993) 11 FRNZ 174 (FC).

64 At 179

65 CD v JMT [Interim personal order] [2012] NZFC 10147; [2013] NZFLR 817 at [28].

66 At [28].

$67 \quad W v K$ [2012] NZFC 9497.

68 Loli v MWY NZFC Auckland FAM-2009-004-1877, 14 January 2011 at [2]. 
are allowed to drink even to excess and imprudently, this can reach a point where a person is no longer able to function. Judge Adams accepted that jurisdiction existed under the PPPRA, saying: ${ }^{69}$

Because of his loss of executive function, s 6(3) cannot have sensible effect. The Court cannot assume, simply because Mr Y started drinking himself to death at a time when he may well have had executive function, that he would necessarily have continued to do so, notwithstanding the mounting medical, social and psychological risks. There is no respect for his personhood in such an approach. The essence of functionality is the retention of some flexibility, some ability to review the wisdom of past behaviours.

He thus ordered that $\mathrm{Y}$ live at a rest home or dementia unit. Crucially for our purposes, he added a supplementary order "[t]hat reasonable force may be used, including by the police if necessary, to transport or return Mr Y to a residential care facility identified in order (1)". This supplementary order was based on evidence that $\mathrm{Y}$ had several times absconded from the residence where he was staying, or had tried to do so.

This latter case is thus part of a line of authorities at Family Court level that have included an element of coercion in the orders that have been made. Concerns that the Act is somewhat hamstrung in this respect may be misplaced. Even the police can be incorporated into the orders that the court makes.

\section{INHERENT JURISDICTION}

The question of the inherent powers of the High Court, strictly speaking, takes us beyond the PPPRA. However, there is an element of symbiosis.

Earlier in this article, reference was made to JMG v CCS Disability Action (Wellington Branch Inc), ${ }^{70}$ a case where it was held on appeal that the Family Court had jurisdiction to make a tenancy order affecting the tenant with whom the protected person was living. Miller $\mathbf{J}$ accepted a submission made by the amicus that the parens patriae jurisdiction could have been invoked to make the order if necessary. However, he preferred to use s 10(4), which he held extended to cover the situation before him. In general, the inherent jurisdiction will not be used if a statutory route is available, all the more so as the Family Court will not share in the inherent powers.

In Britain, an issue was recently resolved by way of the inherent powers. In $D L v$ A Local Authority, ${ }^{71}$ a son lived with his elderly parents and was aggressive towards them. The local authority was worried about the situation and sought a restraining injunction against the son. The

69 At [10].

$70 J M G$ v CCS Disability Action (Wellington Branch Inc), above n 17. See also part IVC above "The UN Convention".

71 DLv A Local Authority [2012] EWCA Civ 253, [2012] 3 WLR 1439, [2012] 3 All ER 1064. 
initial difficulty was that the parents did not fall under the Mental Capacity Act 2005 (UK), the equivalent of the PPPRA. As it happened the father's mental condition deteriorated during the course of the litigation and the 2005 Act was ultimately able to be used in relation to him. With respect to the mother, the High Court used its inherent powers and the Court of Appeal upheld this. It was accepted that the inherent jurisdiction survived the passage of the 2005 Act and could be used in situations that fell outside the statutory scheme. Who then is covered? According to McFarlane LJ: $: 72$

... it is not easy to define and delineate this group of vulnerable adults, as, in contrast, it is when the yardstick of vulnerability relates to an impairment or disturbance in the functioning of the mind or brain. Nor is it wise or helpful to place a finite limit on those who may, or may not, attract the court's protection in this regard. The establishment of a statutory scheme to bring the cases in this hinterland before the Court of Protection would ... represent an almost impossible task, whereas the ability of the common law to develop and adapt its jurisdiction, on a case by case basis, as may be required, may meet this need more readily.

The Judge provided a policy basis for the continuation of this somewhat unbounded jurisdiction: ${ }^{73}$

The existence of "elder abuse" ... is sadly all too easy to contemplate. Indeed the use of the term "elder" in that label may inadvertently limit it to a particular age group whereas, as the cases demonstrate, the will of a vulnerable adult of any age may, in certain circumstances, be overborne. Where the facts justify it, such individuals require and deserve the protection of the authorities and the law so that they may regain the very autonomy that the appellant rightly prizes.

Would the approach just outlined be adopted in New Zealand? It is more extensive than the reference in $J M G$ above to inherent powers as, there, they related to someone who came under the PPPRA. The PPPRA does not purport to remove the inherent jurisdiction preserved by $\mathrm{s} 17$ of the Judicature Act 1908. Nor is the PPPRA described as a code in the way that, for example, the Property (Relationships) Act 1976 is under s 4. Given the unknown situations that may arise where the inherent jurisdiction may turn out to fill a gap and be valuable for vulnerable people, it is suggested that the better view is that the $D L$ decision would be of persuasive value in this country. However, as it deals with people who are legally competent, where is the line to be drawn? Where should the inherent jurisdiction actually stop?

\section{CONCLUSION}

This article has been something of a potpourri of developments in relation to the PPPRA. This is inevitable to a certain extent, given the nature of the Act and the wide range of issues that can arise. Some situations can be very fraught, especially where family conflict exists. In the majority of

72 At [64].

73 At [63]. 
cases, the courts have used a modicum of common sense and produced workable outcomes, protecting the interests and rights of a vulnerable section of our community.

Yet, after 25 years, there is a case for reviewing the Act to see if it still meets the needs of those whom it covers. In particular, its likely increased use to cover old age and placement in institutions may warrant fresh eyes. Further, are the governing principles and objectives ones that hit the right notes for 2013 and beyond? Are the specific powers given to the Family Court tailored in such a way that they can meet new situations as they arise? Does the Act provide for the inclusion of family members and whānau where appropriate, and does it have the right mechanisms for speedily settling disputes, often inter-family ones? Are the procedures too cumbersome and technical? Can the system be streamlined without losing fundamental protections such as representation for the person who is the subject of the proceedings? Despite all these questions, the PPPRA, in whatever precise form, will remain a significant workhorse in the life of the family practitioner, the Family Court and many New Zealanders. 
